\title{
USA's trade policy in the context of global crisis and the decline of North American hegemony
}

\author{
A política comercial dos EUA no contexto da crise global \\ e o declínio da hegemonia norte-americana
}

ARTURO GUILLÉN*;**

RESUMO: A crise global de 2007 reforçou as tendências deflacionárias, assim como a retirada dos países centrais para dentro. Após a Grande Recessão de 2008-2009, a maioria das economias experimentou processos de semiestagnação e deglobalização. A crise acelerou o declínio da hegemonia dos Estados Unidos. Embora mantenham uma vantagem militar esmagadora e mantenham a hegemonia financeira, perderam terreno na produção, no comércio internacional e no investimento direto estrangeiro. A política comercial de Trump acelerará a desglobalização. E enquanto seu corte de impostos teve um efeito positivo de curto prazo no crescimento, será difícil superar a "estagnação secular”.

PALAVRAS-CHAVE: Crise global; desglobalização; política comercial norte-americana; declinação hegemônica dos EUA; estagnação.

ABSTRACT: The global crisis of 2007 reinforced the deflationary tendencies, as well as the withdrawal of the central countries inwards. After the Great Recession 2008-2009, most economies have experienced semi-stagnation and deglobalization processes. The crisis accelerated the decline of the hegemony of the United States. While they retain an overwhelming military advantage and maintain financial hegemony, they have lost ground in production, in international trade and in direct foreign investment. Trump's trade policy will accelerate deglobalization. And while its tax cut has had a short-term positive effect on growth, it will be difficult to overcome "secular stagnation".

KEYWORDS: Global crisis; deglobalization; North American trade policy; USA hegemonic declination; stagnation.

JEL Classification: F4.

\footnotetext{
* Professor - Researcher of the Department of Economics of the Universidad Autónoma Metropolitana Iztapalapa, Mexico, México. E-mail: artguillenrom@hotmail.com. Orcid: 0000-0001-8033-768X. Submitted: Submitted: 22/October/2018; Approved: 14/January/2019.

* * Professor of the "Postgraduate in Social Studies" of the same University. General Coordinator of the international network Red Eurolatinoamericana de Estudios sobre el Desarrollo Celso Furtado (www. redcelsofurtado.edu.mx). Member of the National System of Researchers of Mexico. SEP.
} 


\section{INTRODUCTION}

The objective of this article is to analyze the changes experienced in the trade policy of the United States of America (USA) since the arrival of Donald Trump to the government, which has been characterized by the rise of an aggressive protectionism and the abandonment of multilateral negotiation mechanisms. Protectionism is not a new phenomenon in that country. In fact, USA's conversion into an industrial power was carried out under the auspices of protectionism. Even in the post-war period, in which the United States became the hegemonic power of the capitalist system and assumed the role of leader of trade liberalization, trade barriers, tariff or non-tariff, did not cease to apply.

It is argued that the current trade policy of the US administration responds to the adverse circumstances in which the world economy unfolds and the changes that are taking place in the geopolitical order. The main factors that have produced that dramatic turn in trade policy are, first, the great global crisis that broke out in 2007 which outcome continues to face an environment of radical uncertainty, and, second, the deepening of the decline of the US hegemony, which although its roots go back to the seventies, accelerated with the global crisis. This crisis has led to a scenario of economic stagnation, deflationary tendencies and deglobalization in most of the developed countries, but it has not prevented, up to now, the unstoppable rise of China as an emerging power.

Second section examines the recent development of the global crisis and its relationship with the process of stagnation experienced in most of the old Western powers, as well as the limitations of the economic policy applied by governments and central banks to achieve a vigorous recovery of the economy.

In the third section, the process of declining US hegemony is analyzed in the framework of the fragmentation of world order, the predominance of centrifugal tendencies within it, the formation of new geopolitical alliances and the tendencies towards the constitution of a multipolar order.

The fourth section analyzes the trade policy of aggressive protectionism of the Donald Trump government, which is inscribed as mentioned above, in the context of the crisis and the hegemonic decline of that power. At the same time, this policy is articulated with the ultraconservative, racist and xenophobic strategy followed by the administration with republican support, and which is the ideological cement of the population, mainly Caucasian that allowed Trump to reach the government and achieve its re-election in 2020.

Finally, in the last section, some conclusions are presented.

\section{GLOBAL CRISIS, STAGNATION AND DEGLOBALIZATION}

In 2007, the global economic-financial crisis began. This has been the deepest crisis that capitalism has faced in its long history, more serious and complex than the one faced during the Interwar period of the last century. Its greater severity and 
complexity is revealed not so much in its recessive impact on macroeconomic indicators - which has been, until now, relatively minor in terms of production and employment - , but in its interrelation with other crisis processes such as the environmental collapse, the energy crisis and the food crisis, which were not present during the Great Depression of the 1930s (Guillén, 2015). The multidimensional nature of the crisis - which announces the historical limits of this mode of production - is compounded by the inability of governments and multilateral institutions to find a way out to restore the dynamism that characterized the system in the two decades that followed to the Second World War.

The crisis is immersed, at the same time, as it is a factor of acceleration of a process of tectonic changes in the world's geo-economic and political order. These changes prefigure the end of the unipolar world in force since the fall of the Soviet Union and the birth of a multipolar order yet to be defined. Among the main changes of the present era are the hegemonic decline of the United States and the rise of China and other emerging powers.

The global crisis has driven the deflationary tendencies that have been latent in the world economy for years, as well as the withdrawal of the core countries inwards. Once the Great Recession 2008-2009 ended, most of the developed economies experienced processes of cyclical recovery, but within a general framework of economic semi-stagnation. At the same time, a slow but significant process of trade deglobalization and reinforcement of protectionist policies was detonated.

After the storm of the Great Recession in 2010 began a cyclical recovery process that lasts to date. In the case of the United States, it is the longest cycle in the recent history of US capitalism, even longer than that recorded in the 1960s in the heat of the Vietnam War, or that experienced during the "new economy" bubble of the nineties. But it is also one of the most mediocre expansive phases, which in the theoretical field, has led to the resurgence of secular stagnation theory. That recovery also coincided with the European crisis of 2011, which almost caused the dissolution of European integration, as well as with the continuity of the lethargy of the Japanese economy, whose productive anemia has spread for more than three decades.

The unconventional expansive monetary policies of the central banks followed since the outbreak of the global crisis inflated the assets of these central banks to unprecedented levels, thus preventing the world economy from repeating a depression similar to the one of the 1930s. That policy avoided the increase of open unemployment rates, but failed to substantially reactivate investment or economic growth. The balance sheets of the main central banks of the world accumulate a whopping 19.5 trillion dollars in assets. Of the total figure, the FED has 3.9 trillion, the ECB 5.9 trillion, while the Bank of Japan 4.1 trillion and the People's Bank of China 5.3 trillion. These securities remain on their balance sheets, with no prospect of being able to sell them, since doing so would bring down the prices of the bonds and would stop any attempt of monetary normalization. For a long time now, what is normal in capitalism is a persistent abnormality!

Most of the economies of the developed countries prostrated themselves in a situation of semi-stagnation; financialization remained unchanged, new financial 
bubbles were created and deflationary tendencies remained latent. The inflation that was the main enemy at the beginning of the eighties has paradoxically become one of the most desired objectives of the economic policy of governments and central banks. Practically, since the irruption of the global crisis, the central banks have considered, without being able to achieve a rate of inflation of $2 \%$ per year. The reason for this obsession to increase inflation and the FED's parallel obsession to "normalize" monetary policy is not difficult to understand, since if current price trends continue and if productive stagnation subsists, the debt reduction of the economic agents, it will not be possible to materialize. Furthermore, if a recession or a new financial crisis were to occur, central banks could not use monetary policy as a countercyclical weapon.

As can be seen in Table 1, global GDP registered a downward trend since the beginning of the "recovery" in 2010, going from $5.1 \%$ that year to $3.1 \%$ in 2016 . GDP growth in developed countries has been anemic and emerging economies have seen their growth slowed down (including China) or have entered recession, as is the case in Brazil, Argentina and other countries. During this period, the US GDP has increased by around $2 \%$ per year, while the economies of the Eurozone and Japan have recorded even lower and more oscillating growth rates. Between 2002 and 2016, average GDP growth in the United States was 1.9\%, representing almost half of the 3.5\% achieved during 1947-2001 (Ross and Navarro, 2016: 3). In 2017 there was a slight upturn as the global GDP grew 3.7\%, while the US economy grew $2.2 \%$. However, as noted below, this upturn lost strength at the end of 2018 .

Table 1: Main economic indicators Rates of growth (\%)

\begin{tabular}{|l|c|c|c|c|c|c|c|c|c|c|c|}
\hline \multicolumn{1}{|c|}{ Concept } & 2007 & 2008 & 2009 & 2010 & 2011 & 2012 & 2013 & 2014 & 2015 & 2016 & 2017 \\
\hline WORLD GDP & 5.2 & 3 & -0.6 & 5.2 & 3.8 & 3.2 & 3.3 & 3.4 & 3.2 & 3.1 & 3.7 \\
\hline USA GDP & 2.2 & 0.4 & -2.7 & 2.5 & 1.8 & 2.2 & 2.2 & 2.4 & 2.6 & 1.6 & 2.2 \\
\hline EUROZONE GDP & 2.6 & 0.5 & -4.2 & 1.9 & 1.4 & -0.4 & -0.5 & 1.5 & 2 & 1.7 & 2.6 \\
\hline JAPAN GDP & 2.1 & -1.2 & -5.4 & 2.4 & -0.8 & 2.2 & 1.6 & 0.6 & 1.2 & 0.9 & 1.7 \\
\hline $\begin{array}{l}\text { VOLUME OF WORLD } \\
\text { TRADE }\end{array}$ & 7.2 & 2.8 & -10.7 & 12.7 & 6.9 & 2.7 & 3.5 & 3.4 & 2.7 & 1.9 & 5.2 \\
\hline $\begin{array}{l}\text { PRICES OF PRIMARY } \\
\text { GOODS (fuels) }\end{array}$ & 10.7 & 36.4 & -36.8 & 27.9 & 31.9 & 1 & -0.9 & -7.5 & -47.2 & -15.9 & 23.4 \\
\hline $\begin{array}{l}\text { PRICES OF PRIMARY } \\
\text { GOODS (non fuels) }\end{array}$ & 14.1 & 4.5 & -18.7 & 26.3 & 17.7 & -10 & -1.2 & -4 & -17.5 & -9.4 & 6.8 \\
\hline $\begin{array}{l}\text { CONSUMER PRICES } \\
\text { ADVANCED COUNTRIES }\end{array}$ & 2.1 & 3.4 & 0.1 & 1.6 & 2.7 & 2 & 1.4 & 1.4 & 0.3 & 0.7 & 1.7 \\
\hline
\end{tabular}

Source: World Economic Outlook database, IMF. October 2018.

Due to the crisis, international trade collapsed, leaving the external market as an important escape valve for semi-stagnant economies no longer. China itself was driven to modify its economic model, so that it can rely more on domestic consumption. While foreign trade in goods increased at twice the rate of world GDP in the period before the global crisis, since 2010 the increase in foreign trade has 
registered similar rates and even lower than the growth of GDP (Table 1 and Figure 1). This means that the international movement of goods has not only lost dynamism, but has also slowed down the intense process of trade globalization that began in the 1970s.

Figure 1: GDP RATES OF GROWTH (\%) 1980-2017

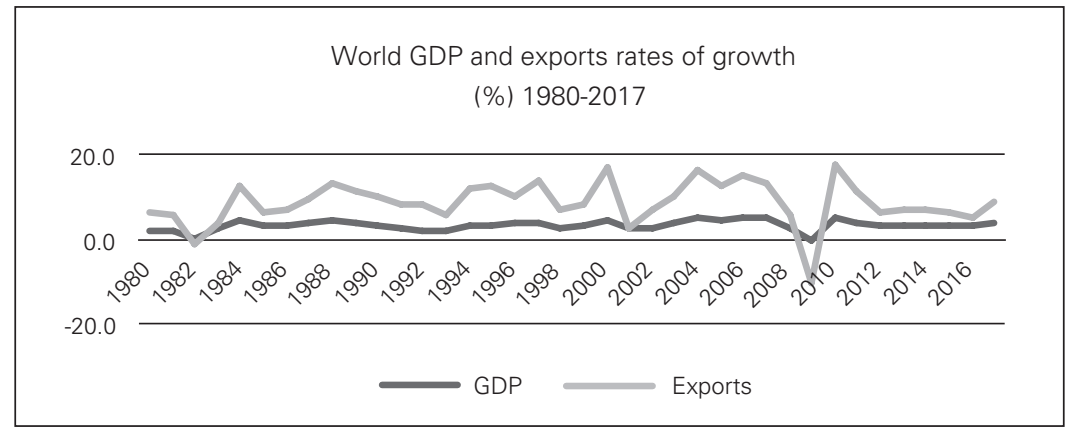

Source: World Economic Outlook database, IMF. October 2018.

Since the second postwar period, trade globalization, which we can measure through the degree of openness of the economies (world exports as a percentage of GDP), gained momentum. As can be seen in Figure 2, that process accelerated markedly after the great crisis of the late 1960s. Given the narrowing of domestic markets due to the fall in the rate of profit, the leading sectors of the capital of the main developed countries projected their markets and capital abroad (Guillén, 2007), inaugurating the stage of neoliberalism, a synthetic concept, which covers various processes, including trade and financial globalization.

Figure 2: Trade as percentage of GDP 1961-2017

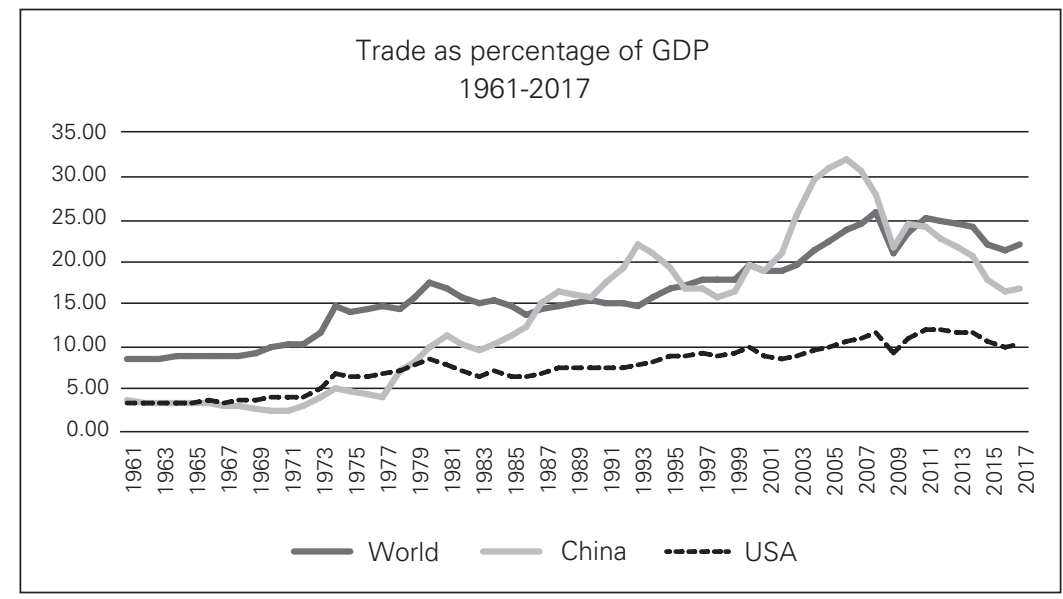

Source: World Bank. 
Trade globalization gained strength in the eighties with the triumph of neoliberalism and intensified further in the decade of the nineties with financial globalization and with the arrival of "the new economy" based on the development of the Internet and telecommunications. The export coefficient of the world economy went from representing $10 \%$ of the world GDP in 1970, to $17.4 \%$ in 1980 and $19.5 \%$ in the year 2000 . Its maximum point was reached in 2008 when it registered $25.8 \%$.

On the contrary, since the great recession of 2008-2009, this index has tended to fall sharply, indicating a clear process of trade deglobalization linked to economic stagnation and the rise of protectionism. In 2016, the export coefficient was around almost five percentage points lower than in the period before the global crisis $(21.2 \%)$. And although the index rebounded slightly in 2017 to $22 \%$, it is foreseeable that such an upturn will not be sustained due to the rise of protectionism policies of the Donald Trump and other centrifugal forces as Brexit and others.

The reversion of globalization is not confined solely to merchandise trade. This begins to affect foreign direct investment (FDI) flows. After having rebounded at the end of the Great Recession 2008-2009, they have been declining since 2015. The decline was accentuated in 2017. According to data from UNCTAD (2018a), global FDI flows fell $23 \%$ during 2017 . The decrease was more pronounced in the developed countries and in the so-called economies in transition (ex socialist countries), while the flows to the underdeveloped economies remained stagnant. In that negative behavior of the FDI flows, had an important influence the marked decrease in the flows linked to the mergers and acquisitions processes. These flows fell from 887 billion dollars (bd) in 2016 to 694 bd in 2017. In the first half of 2018, FDI flows continued to fall decreasing 41 percent (El Financiero, 2018). In this reversal has played an important role the tax reduction decided by the Trump administration, which has led many TNCs to repatriate capital to the United States to benefit from the tax cut.

According to UNCTAD (2018a), the reflux of FDI is not only due to the climate of uncertainty that surrounds the world economy, but also influenced by a lower profitability of capital. The rate of return has decreased consistently since 2012, going from $8.1 \%$ in this year to $6.7 \%$ in 2017 . This decrease has affected practically all regions of the globe. The phantom of the rate of profit reappears although neither neoliberals nor Keynesians want to see it. The search for high returns in financial markets in order to maximize profits is explained by the stagnation of the investment process and the lower expectations of profit in the productive sphere of the economy.

Since the volatility of financial markets intensified in April 2018, financial globalization resented the tide change with the contraction of portfolio capital flows to the so-called emerging countries. According to data from the Institute of International Finance (IIF), these flows decreased $9.5 \%$ during 2018, while capital outflows from the markets of these countries speed up (Europa Press, 2018). If China is excluded, the reduction is extended to $30 \%$. Among the factors that have contributed to this incipient process of financial deglobalization, are the three interest 
rates increases decreed by the FED in 2018, the appreciation of the dollar, and the appearance of strong currency devaluations in Argentina, Turkey and Brazil.

Briefly, the world economy is more than eleven years old since the beginning of the cyclical recovery. It has been a long phase, but unequal and fragile, to the point that even in the dominant circles of capital there is great uncertainty about its course. On the other hand, heterodox analysts consider that the global crisis that started in 2007 has not yet been solved (Roberts, 2016 Roubini and Rosa, 2018 Guillén, 2015).

The IMF itself recognizes that at the present time the risks are greater. The Global Financial Stability Report (GFSR) of April 2018 published by that agency was explicit about the risks confronting the "recovery". It states that:

"Short-term risks to financial stability have increased somewhat relative to the previous GFSR, and medium term risks continue to be elevated. Financial vulnerabilities, which have accumulated during years of extremely low rates and volatility, could make the road head bumpy and could put growth at risk [...] Central banks may respond to higher inflation more aggressively than currently expected, which could lead to a sharp tightening of financial conditions. This tightening could spill over to risky asset prices, bank dollar funding markets, and both emerging market economies and low-income countries, as discussed below" (IMF, 2018: xi).

UNCTAD (2018b) makes a deeper analysis of the situation and considers the tendency of governments and central banks to rely almost exclusively on monetary policy to overcome the crisis to be wrong:

"The decade-long strategy of reviving growth through unorthodox monetary means ("'quantitative' easing”) in the advanced economies had only limited success in spurring income and employment growth. The persistent weakness of effective demand, compounded by post-crisis deleveraging by households and firms, dampened productive investment, while higher income inequality and lower employment rates prevented a strong rebound of consumption. It does not help that governments remain reluctant to spend to support growth. The result is a new normal of low growth" (UNCTAD, 2018: 13).

For this organization, rather than facing a return to normalcy, we would be facing new financial turbulences:

"The scenario then is one of instability in many forms. The likely emerging scenario, in the absence of quick proactive macro policy measures by governments, is as follows: net outflows of capital, especially of portfolio capital, from emerging markets, are triggered largely by monetary tightening and increases in interest rates in the United States and other advanced countries; the consequent depreciation of currencies is then 
worsened by speculative attacks, even as domestic inflation is triggered by the depreciation; debt service payments valued in domestic currency, on substantially increased corporate debt, rise sharply, precipitating default and bankruptcies; and this further depresses investment precisely at a time when it was expected to revive" (Ibid: 24).

Indeed, the risks of greater financial turmoil are high. These have been presented openly since the last quarter of 2018. There is no need to be surprised. The US economy and the rest of the economies inserted in financial globalization (which includes the so-called emerging countries of the periphery), despite the severity of the 2007 crisis, continued to practice a "regime of accumulation dominated by finance" in which speculative operations are an essential, not a subsidiary, part of the operation and reproduction of larger capitals, that is, of monopoly-financial capital. The financial regulation instead of strengthening after the irruption of the crisis (except the light effort of the Dodd-Frank Law, now blurred), has opted to continue with deregulation, especially after the arrival of the Trump administration. In addition, little was done to solve the global imbalances, which played an important role in the financial bubbles that led to the crisis, and which instead of decreasing have increased.

\section{THE HEGEMONIC DECLINE OF THE UNITED STATES AND THE GEOPOLITICAL RECOMPOSITION OF THE WORLD}

The decline of the hegemony of the United States in the world was exacerbated by the irruption of the global crisis of 2007 . However, this process of decline did not begin then, but several decades earlier. The unquestionable and stable hegemony exercised by the United States in the postwar period, due to the exceptional conditions created by the armed conflict - the destruction of European countries; the conversion of the United States into the main creditor economy with the largest gold reserves; his new role as a gendarme of the world and guardian of the so-called "free world" in the face of the rise of the Soviet Union, etc. - began to erode at the end of the sixties. As I have stated in other texts (Guillén, 2007, 2015), several economic and political factors contributed to its weakening: the cracking of the international monetary system based on the gold dollar standard; the beginning of a new "great crisis" (labeled the "crisis of the seventies", but which actually began in the late sixties), which put an end to the "Fordist accumulation regime" that accompanied the long boom of the postwar period; the rise of two great powers: Germany and Japan, which exacerbated competition in the world market; and the defeat of US imperialism in the Vietnam War.

The establishment of neoliberalism in the eighties, during the administration of Ronald Reagan allowed stopping the US decline, through the application of a radical and aggressive monetary policy (under the leadership of Secretary of the Treasury Paul Volcker). This policy not only succeeded in stopping the strong in- 
flation of the previous decade, but also prevented the decline of the dollar and its eventual abandonment as a key currency of the system. At the same time that policy triggered the external debt crisis in the peripheries of the system.

Neoliberal globalization was promoted, through trade opening and later, in the nineties, financial globalization was deployed, supported by the emergence of the "new economy" based on the Internet, telecommunications and biotechnology.

Neoliberal economic-financial globalization was a project of monopoly-financial capital - with the United States at the forefront, to resolve the contradictions of the so-called "great crisis" of the 1970s. Globalization allowed the imperial power to recover the initiative in the remodeling of capitalist economies and represented a new source of profits for the transnational capital through the relocation of its capitals in the peripheries. The space for valorization of capitals was greatly expanded with the collapse of the Soviet Union and the European socialist camp and with the insertion of China into neoliberal globalization.

However, the "regime of accumulation dominated by finance" aggravated the contradictions of the system, by weakening financial structures. This regime was at the origin of the systemic financial crises experienced since the nineties: beginning with the "tequila crisis" in Mexico in 1994-1995, going through the Asian crisis of 1997-1998, the NASDAQ crisis of 2001, until ending in the global economic-financial crisis of 2007. With this last crisis, the process of decline of the US hegemony that had been contained with globalization accelerated provoking a major change in the correlation of forces of the powers in the world system.

Neoliberal globalization caused profound changes in the structure of the world economy. During the last three decades, the United States began an unequal but unstoppable process of declining hegemony since the Second World War and became the largest debtor on the planet, while China emerged as the main industrial and manufacturing workshop and first trade power. China was consolidated, as the main creditor center, while the United States, as happened with the United Kingdom in the Interwar period, became the main debtor. This country became a highly rentier economy that uses its monetary, financial and military supremacy to maintain its hegemony. As S. Roach points out between the United States and China, there exists a "codependence", which has been beneficial for both parties. The United States, the debtor country, benefits from the importation of Chinese products at low prices and the secure purchase by the Asian power of debt securities generated by its growing external deficit, while China benefits from counting with a large market for its exports and for the accumulation of large monetary reserves (Roach, 2014).

The dynamic pole of the world economy leaned definitively towards Asia, and mainly towards China. The impressive development of China gained strength with the economic reforms introduced by Deng Xiaoping from $1979 .{ }^{1}$ China abandoned

\footnotetext{
${ }^{1}$ As some analysts have argued (Petras, 2015), the spectacular economic takeoff of China would not have been possible without the previous development achieved under "real socialism", with the
} 
the model of "state socialism" established since the triumph of the revolution in 1949 , similar in many respects to that followed by the Soviet Union, and replaced it with a kind of "national and popular state capitalism", under the direction of the Chinese Communist Party. An export model was established based on the impulse of capitalist production relations and external opening. This was formalized with the entry to the World Trade Organization (WTO) in 2001. In this way, China inserted itself into neoliberal globalization, but without passively accepting the Washington Consensus recipes and maintaining autonomy in the design and application of its macroeconomic policies. Under this model, euphemistically called by Chinese officials "market socialism", China achieved over three decades, GDP growth rates of the order of $10 \%$, and since 2007 when the global crisis of capitalism began, and in a global framework of semi-stagnation, has managed to sustain growth rates of over $6 \%$.

This country increased its participation in the world GDP progressively; its participation increased almost nine percentage points as it evolved from $1 \%$ in 1980 to $9.4 \%$ in 2014 . However impressive these numbers are, they minimize the relative weight of China in the world economy. If instead of using the GDP data at constant prices - we use the data in terms of the purchasing power the currencies (PPP, for its acronym in English), which eliminates the distortion of the exchange rates in the data - , the rise of China turns out to be much more spectacular and the North American decline more pronounced. As can be seen in Figure 3, the share of Chinese GDP in world production has continued to increase during the last decade, going from $4.5 \%$ in 1990 to $7.8 \%$ in the year 2000 . And between this last date and 2017 , its participation more than doubled when it reached $18.6 \%$. On the other hand, the participation of the United States in world GDP remained stable at around $21 \%$ during the nineties, but it has been falling steadily, year after year, since the crisis of 2007. In 2017, it represented only $15.3 \%$ of world GDP, three percentage points below the Chinese GDP.

China is now the leading economy of the world, displacing the US, still hegemonic, from that place. And if Marx was right in that production is the determining element of economic power over circulation, as Weeks (2016) reminds us, then there seems to be no doubt that we are experiencing a period of hegemonic transition, in which China has assumed leadership and in which the United States preserves its hegemony, through extractive mechanisms (financial rents, among them) and military. The North American is increasingly a hegemony without consensus, or in other words, domination without hegemony.

Where is the hegemonic transition going? The hegemonic transition does not necessarily mean that China, the main emerging power, will necessarily and gently

development of basic industries and the reorganization of peasant production. Unlike the Soviet Union, which under the command of Stalin, and faced with the threat of a new world war, carried forward the forced collectivization of the countryside (with its flow of millions of peasants killed or deported to concentration camps), Chinese communism supported the worker-peasant alliance, both to make the revolution, and to promote the development of the productive forces. 


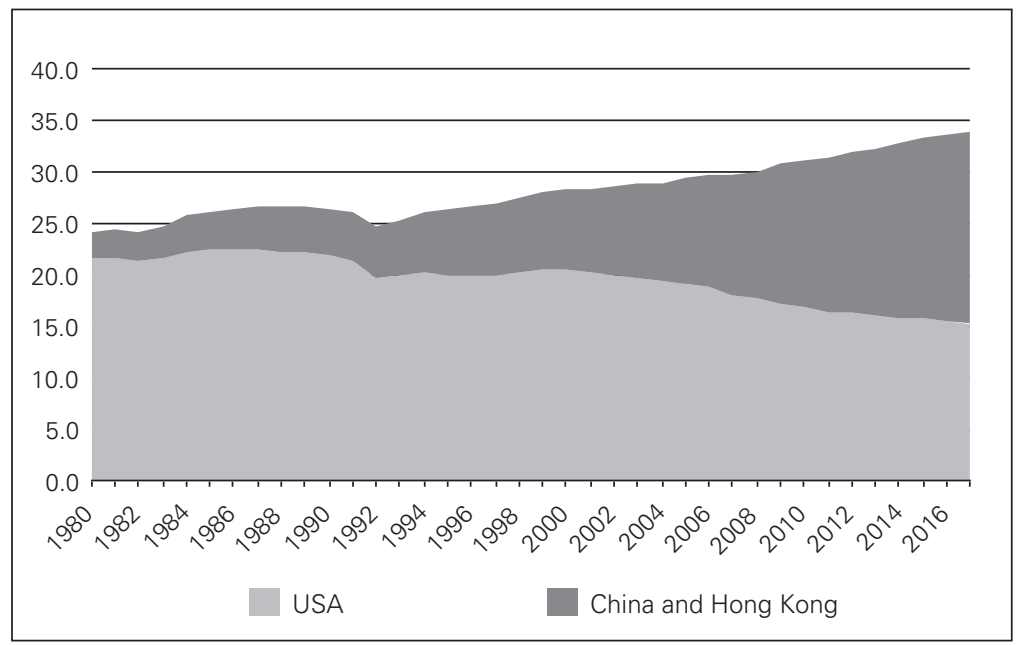

Source: World Economic Outlook database, IMF. October 2018.

will replace the United States. Such automatisms do not exist in history. It could occur that such transition would lead to the emergence of new armed conflicts, as happened with the rise of British hegemony in the $19^{\text {th }}$ century, or that of US hegemony in the Interwar years (1918-1938); or the transition could lead towards a multipolar order with consensual rules, for which there are no precedents, nor do there seem to be conditions nowadays; or that it leads to a global systemic chaos, which seems to be, increasingly, the most likely scenario.

Unlike the period of undisputed US hegemony (1948-1970), in which centripetal forces predominated in the world system, centrifugal forces currently dominate, similarly, though not identical, to that prevailing in the Interwar period. Fragmentation is on the agenda. Examples abound: Brexit; the rise of xenophobic and Eurosceptic movements and parties in Europe; Ukraine; the abandonment of multilateralism on the part of the Trump administration; the trade war; the state of anomie in which the Middle East develops since the military intervention in Iraq, or in which many countries of the peripheries live; etc.

The Chinese leadership is irrefutable, also, in the trade field. China has become the world's leading exporter, displacing the United States from that place. Its share in world exports, including data from China-Hong Kong increased from an insignificant $1.8 \%$ in 1980 to $15.8 \%$ in 2016 . In the same period, the United States reduced its share from $12 \%$ to $8.7 \%$. Germany, which had become the world's leading exporter in 1990, currently ranks third. It is true that part of the Chinese export success depends on the operation of transnational corporations (TNCs), mainly North American, which in the framework of globalization, have relocated their capitals to China and other countries in the peripheries. Chinese goods exports by TNCs increased from 5.6\% of the total in 1987 to $58.9 \%$ in 2006 (Gouyou, 2010: 50). 
Figure 4: Share of world exports (\%)

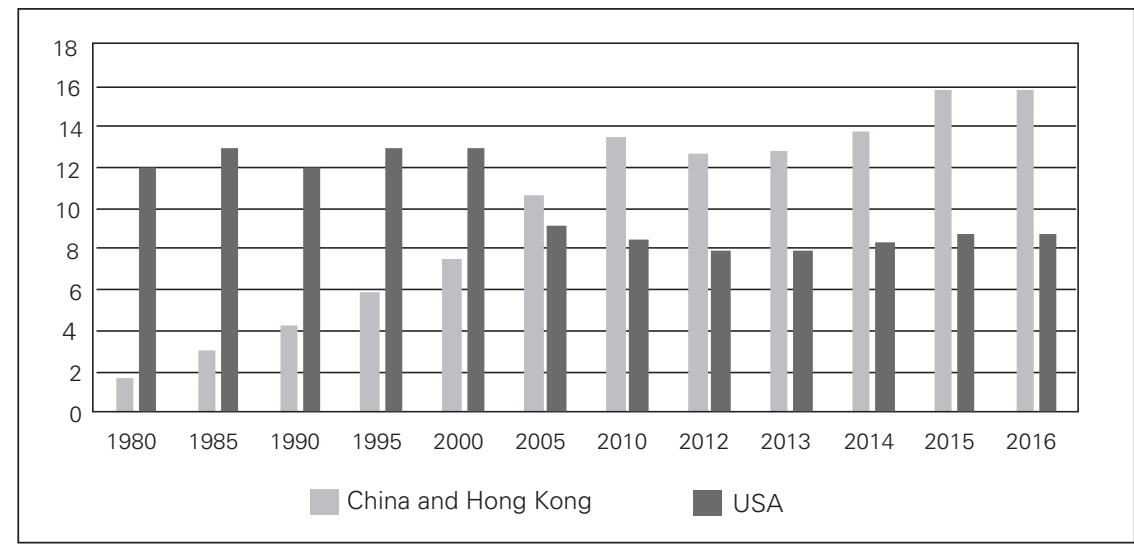

Source: UNCTAD.

China's rise to trade leadership is clearly noted when trade in manufactures is examined. In this field, China has also displaced the United States. Whereas in 1980 the Eastern power only absorbed $0.8 \%$ of the exports of manufactures, in 2017 its participation amounted to $21.4 \%$ (Figure 5). This represents more than twice the share of the United States, which saw its share fall, from $13 \%$ in 1980 to $9.3 \%$ in 2017. The old industrial powers of Europe, as well as Japan, have seen substantial reductions in their share of foreign trade of manufactures for the benefit of China and the NICS of East Asia. That trade is not composed as it was at the beginning of the process, by the sale of cheap manufactures of low technological content, but increasingly by cutting-edge industries of the world economy.

Figure 5: Manufacturing exports as $\%$ of total manufacturing exports

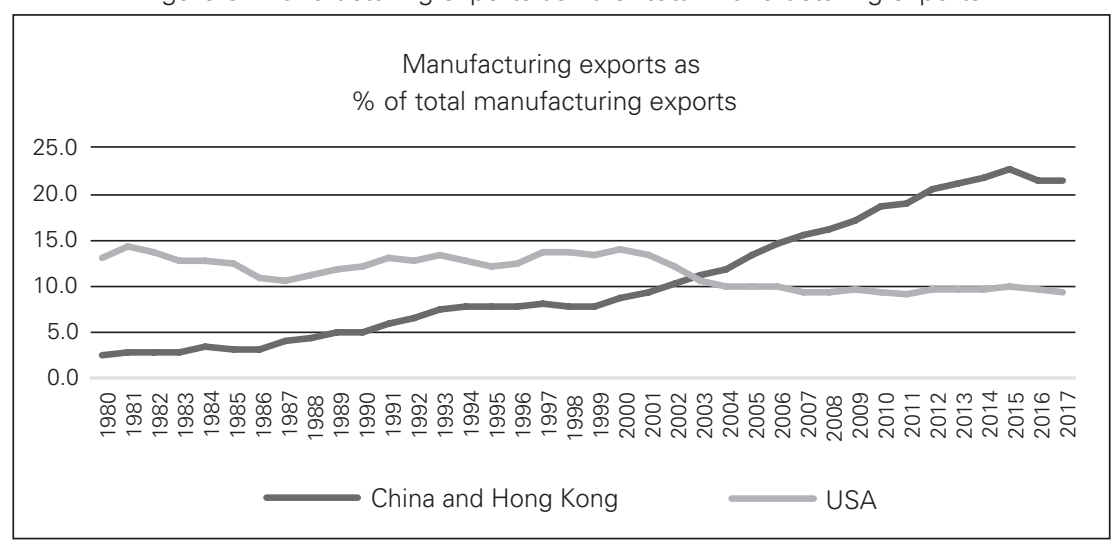

Source: OMC.

Information technology and telecommunications are a good example. In the nineties, Chinese participation in foreign trade in these branches was insignificant. 
However, in the year 2000, China ranked $13^{\text {th }}$ in information technology and $15^{\text {th }}$ in telecommunications equipment. Only four years later, it had jumped to the first place in both branches (Roach, 2014: 114), which shows that this country has not only been successful in absorbing and adapting technologies, but, increasingly, in the development of new technologies. In 2010, 135,000 new patents were registered in that country, $25 \%$ more than in 2009. In that category, it ranks third in the world, only behind Japan and the United States (Ibidem: 155). The enormous technological development reached by China in a very short time, has just become evident with the landing made by a satellite on the dark side of the moon, an objective that has not been reached by North Americans or Russians. That feat not only reveals that the great oriental power plays a more than outstanding role in the investigation of space, but that in the military field it has a ballistic park that competes with that of Russia and the United States.

The emergence of China as a power is not confined to production, scientific and technological development or foreign trade. It also covers the financial sphere. In the case of foreign direct investment (FDI), this country is not only a very important recipient of FDI flows (the second largest in the world), but also plays an increasingly important role in the export of capital. The foregoing does not have to be cause for surprise, given its position as the main creditor center of the world. As it happened before with the old capitalist powers, China uses its enormous trade surpluses to place its surplus capital abroad, mainly in the countries of the periphery of Latin America and Africa. The reasons for the international expansion of their capital are the same that have always driven the corporations of the great powers: expand their markets, ensure safe sources of raw materials, develop infrastructures and expand their area of influence.

The United States remains the main exporter of capital in terms of FDI, but China is about to reach it. In 2017, China absorbed $14.5 \%$ of the outflows, while the United States was responsible for $23.9 \%$ of the world total.

In terms of the stock of capital accumulated by the FDI, there are also important changes with the internationalization of the postwar period and mainly with neoliberal globalization. The United States has seen its position as the main exporter of capital constantly reduced, going from $35 \%$ of the stock of foreign FDI in 1960 to $33.6 \%$ in 2000 and $24.8 \%$ in 2017 . What stands out in this aspect is the rise of China, of the countries of Southeast Asia and of the developing countries. Chinese participation, including Hong Kong, rises from virtually nothing in 1960 to $10.7 \%$ in 2017 , higher than any other European power, including Germany.

Along with its growing export activity in FDI flows, China has multiplied loans from his government and development banks, especially to countries of the peripheries for the realization of infrastructure projects and other purposes, aimed at opening space for Chinese investments in primary-extractive activities. It is estimated that for these purposes it disbursed 120 billion dollars in Latin America, between 2005 and 2014, while in Africa it allocated 53million dollars between 2000 and 2010 (Télam, 2015).

The Chinese government recently presented its "China 2025" strategy focused 
on turning its country into a thirty-year span into a technological power that leads innovation on a global scale. This strategy is inserted in the objective of promoting a development model less dependent on exports and more focused on its growing internal market, and on privileging the quality of production over quantitative goals. The star project of the new strategy is the so-called "New Silk Road", which aims to link, through ambitious road, railway and seaports, to Asia with Europe and Africa. The project covers 65 countries that represent $30 \%$ of world GDP. For its implementation the Chinese government created a fund of 40 million dollars (md), as well as credit lines for $60 \mathrm{md}$.

\section{US TRADE POLICY IN THE CONTEXT OF ITS HEGEMONIC DECLINE}

Stagnation, deglobalization and deflation are processes that condition the foreign policy of the United States and, more particularly, its trade policy. These processes come from behind and cover the main capitalist economies for several decades, but they were exacerbated by the global crisis of 2007. Because of them, social discontent against neoliberalism took root in large sections of the population that did not see in their pockets the benefits promised by their propellers. The neoliberal consensus between social democrats and traditional right-wing parties began to fracture, prompting the emergence of left wing and far-right movements opposed to neoliberal globalization. Brexit is in the United Kingdom, leading to the separation of this country from the European Union, and the triumph of Donald Trump in the United States, through a fascist, xenophobic, protectionist and deglobalizing discourse, are a part of these processes of fragmentation of the world economy.

To reach the government and hold on to it, Trump uses a racist discourse, which goes deep into his political base negatively affected by neoliberal globalization. It's not that that white population has suddenly become racist with Trump. It is, rather, of broad layers of the white population that have historically had a racist ideology and culture, and that find in Trump's supremacist discourse a foothold for their way of conceiving their country and the world, as well as for the explanation of your current problems. To fuel racism, a new enemy has been built: immigrants (mainly Latinos) and radical Islamists, in the same way that, in other historical conditions, Hitler blamed the Jews for the ills of Germany. In this context, the construction of the wall on the Mexican border is located, which has become an icon of Trump's political strategy.

In the economic field, the Trump administration has assumed a protectionist and anti-globalization discourse. Some authors have misinterpreted this bias as the end of neoliberalism and globalization. Rather than breaking with neoliberalism and free trade, the US government uses its contradictions with China and other countries, as well as the renegotiation of trade agreements such as NAFTA, to strengthen US power and impose conditions more favorable to their interests. As Palley points out, it is, more than anything, an "anti-globalization circus" (Palley, 2017). In other words, free trade under new forms, which in the current stage of 
capitalism, is a "corporate mercantilism". Along with the anti-globalization and protectionist discourse, an arsenal of measures that reinforce neoliberalism, such as financial and environment deregulation measures.

The economic strategy and trade policy was outlined in the presidential campaign by Wilbur Ross, former leader of a "private equity fund" and current Secretary of Commerce, and by Peter Navarro, professor of Economics and Public Policy from the University of California, Irvine, and currently Director of the White House National Trade Council, recently created advisory office. The axes of this strategy have been validated by the actions undertaken by the Trump government. Navarro is the author or co-author of several books, including The Coming China Wars (2006) and Death by China (2011). In this last book, Navarro and Autry evaluate the role of China in the world economic and political order, as well as the repercussions that the rise of the Asian power causes in the functioning of the economies, and in particular of the North American economy. With a language that recalls the anticommunist discourse of the most tense days of the Cold War, he describes the Asian giant as "the planet most efficient assassin" (2011: 1). It defines the Chinese economy as a "perverse brand of communist style of "State Capitalism", which "has deployed a potent mix of mercantilism and protectionist weapons to pick off America's industries, job by job, one by one" (2011:2). Among other measures taken by China, the author mentions "massive illegal export subsidies, the rampant counterfeiting of US intellectual property, pitifully lax environmental protections and the pervasive use of slave labor". But the most powerful weapon, has been, in his opinion, "a shamelessly manipulated currency", which stimulates exports "and has led to a ticking time bomb in the US-China trade (Ibidem)".

In a document of Trump's presidential campaign, Ross and Navarro (2016) state that the main objective of the economic program of the Trump administration is to overcome economic stagnation and significantly increase economic growth and job creation. Upon arriving at the government, Trump himself has promised to achieve an annual GDP growth of $4 \%$.

According to the interpretation of Ross and Navarro, economic stagnation is not the result of structural problems of the US economy or the effects of the global crisis, but mainly of having ignored "the significant roles that higher taxes and increased regulation have played in inhibiting US economic growth since the beginning of the 21st century, as well as our ability to fix the problems" (2016:3).

To achieve the proposed growth targets, they propose as main measures: a) reduce the external deficit through a thorough revision of trade agreements and trade policy; b) cut income taxes of corporations and individuals; c) accelerate the deregulation of economic activities, including environmental and financial regulations and; d) detonate an ambitious infrastructure construction program.

The Trump's policy is presented as an anti-free trade, protectionist and unilateral policy. The objective is to drastically reduce the trade balance deficit, which is around 500 billion dollars and 800 thousand if the surplus of the balance of services is excluded. It is a trade policy that recovers the principles of mercantilism doctrine rejected by economic thought since the time of Adam Smith — by simplis- 
tically assuming that eliminating the external deficit will automatically translate into growth in domestic production and employment. One of the first measures announced by the government was to withdraw from the TTP, a globalization project promoted by Obama, cancel or renegotiate the North American Free Trade Agreement (NAFTA), with the justification of turning the victim of that asymmetric treaty - Mexico - , in the culprit of the problems faced by the United States, which, incidentally, reinforces its racist ideological campaign against Mexican and Central American migrants.

The Trump's economic strategy rests on two pillars: a fiscal policy that recovers the so-called "supply side economics", developed by Wanniski (1978) and based on the "Laffer curve", by which it is argued that the higher the taxes, the lower tax revenues will tend to be. That theory was applied by the government of Ronald Reagan, under the assumption that the low taxation of the rich and deregulation would detonate investment; and a mercantilist trade policy, which assumes that the substantial reduction in the of the US trade deficit will return jobs to home.

The application of protectionist policies is not a new fact in the United States. In fact, US capitalism has always resorted to protectionism, practically since the formation of the Republic, including the period of the second postwar period when, once world hegemony was conquered, it became the spokesman for "free trade".

Protectionism itself is not good or bad, but depends on the macroeconomic objectives that it serves. Neither, free trade is always good and beneficial for all the contenders, as neoliberals believe. In the unilateral and aggressive protectionist offensive of the Trump administration there are new elements, which it is necessary to consider. It is not only a policy of defending the internal market against the disruptive effects of globalization, but it is the result of a long-term global crisis, whose development and outcome is very uncertain, and in the course of which the decline of the United States as a global hegemon has deepened.

The Trump's mercantilist policy of reducing the external deficit also confronts serious difficulties for its realization. This has been presented as an anti-free trade and protectionist policy. The objective is to drastically reduce the deficit in the trade balance, target that has not been met to date.

At first glance, the anti-free trade and protectionist label of the Trump government is plausible. As I said above, one of the first measures announced by the government was to withdraw from the Trans-Pacific Treaty (TTP), as well as cancel or renegotiate NAFTA. In the latter case, to justify its revision - euphemistically called "modernization" or "actualization" — the victim of that asymmetric treaty - Mexico - became the culprit of the problems faced by the United States. Finally, in November 2018, after presenting Trump to NAFTA as "the worst commercial treaty in the history of the United States", the three signatory countries approved its renegotiation. The new agreement, now baptized with the name UMSCA, for its acronym in English, is an arrangement clearly favorable to the US administration. Although Canada and Mexico managed to maintain the trilateral nature of the agreement, the Trump's objective of returning jobs to the United States was fulfilled. For this purpose, the rules of origin of the automotive sector were raised 
from $62.5 \%$ to $75 \%$, while establishing that $40-45 \%$ of the value of the vehicle must be produced by workers who earn more than 16 dollars per hour, which It involves the transfer of processes from Mexico to the US and Canada. The rules of origin clause are set also against China and the Southeast Asian countries that had used the NAFTA platform to introduce cheaper parts and inputs. ${ }^{2}$

While the integration projects promoted by previous administrations are abandoned or revised, the multilateral trade strategy is abandoned and the signing of bilateral agreements is favored. ${ }^{3}$ To date, only the bilateral treaty with South Korea has been revised, although the possibility of signing bilateral treaties with Japan, the United Kingdom and India is mentioned.

The Office of the US Trade Representative defines the new commercial strategy in the following terms:

"The overarching purpose of our trade policy - the guiding principle behind all of our actions in this key area - will be to expand trade in a way that is freer and fairer for all Americans. Every action we take with respect to trade will be designed to increase our economic growth, promote job creation in the United States, promote reciprocity with our trading partners, strengthen our manufacturing base and our ability to defend ourselves, and expand our agricultural and services industry exports. As a general matter, we believe that these goals can be best accomplished by focusing on bilateral negotiations rather than multilateral negotiations - and by renegotiating and revising trade agreements when our goals are not being met. Finally, we reject the notion that the United States should, for putative geopolitical advantage, turn a blind eye to unfair trade practices that disadvantage American workers, farmers, ranchers, and businesses in global markets" (USTR, 2017: 13).

In other words, for the current US government it is not a question of abandoning free trade agreements, but of refocusing them preferably through bilateral channels. That international trade must be not only "free", but also "just". But just for whom? Obviously for the United States. What is being sought now is to review the agreements in order to favor the USA more, by imposing on the counterparts the strength of the geo-economics and geopolitical interests of the TNCs and the government. It is about using the still hegemonic position of the USA, to increase its share in international trade, and try to counteract a world that slides towards multipolarity.

\footnotetext{
${ }^{2}$ The anti-Chinese objective is openly manifested in a clause of UMSCA, which states that the signatory countries cannot sign trade agreements with countries that do not have a "market economy", an allusion to the Asian giant. If a country did so, the other parties would cancel the trilateral agreement and replace it with a bilateral one.

${ }^{3}$ In fact, the preference for bilateral agreements in US trade policy is not new, but begins with the administration of George W. Bush, after the failure of the Free Trade Agreement of the Americas (FTAA) in 2005, given the refusal of the progressive governments of South America.
} 
The number one objective of the US protectionist strategy is China, a country that has become the main external enemy, not only because of its economic strength, but also because of its growing technological, military and diplomatic force. Trade policy is only an instrument of a broader geostrategic policy focused on preserving US hegemony and stopping the advance of the Asian giant. It is not about the end of "free" trade, but the reinforcement of "corporate mercantilism" that has been the hallmark of neoliberal free trade agreements, as well as the use of "aggressive protectionism" as denounced by Hilferding (1973) at the dawn of modern imperialism.

The anti-Chinese turn of the US trade policy does not begin with Trump but goes back to 2005 during the administration of George W. Bush. In April of that year a bipartisan majority of the Senate passed the Schumer-Graham Amendment declaring China "currency manipulator". Schumer declared then "it's time to speak softly and carry a big stick". Later in 2010, during the Obama administration, the House of Representatives passed the Currency Reform for Fair Trade Act, and in 2011 the Senate passed the Currency Exchange Rate Oversight Act. Both initiatives, although not implemented because they were not approved bicameral, blamed China for manipulating its exchange rate and sought to impose compensatory tariffs (Roach, 2014).

From words and papers, the United States turned to the facts. The protectionist offensive began with the establishment of tariffs on solar panels in January 2018. In March of that year they established tariffs of $25 \%$ on steel and $10 \%$ on aluminum, which was applied in a general manner, with the exception of some countries. To date, these charges have been maintained even for Canada and Mexico, despite having signed the UMSCA. The offensive increased in June and it became an authentic trade war, with the USA and China as the main actors. On June 15, Trump confirmed the imposition of a tariff of $25 \%$ to 50 billion Chinese exports, alleging unfair practices and theft of intellectual property. China's trade minister accused the United States of starting a trade war and said China would respond with similar tariffs to US imports. Three days later, the White House declared that the United States would establish additional tariffs of $10 \%$ to another 200 billion Chinese imports, if China responded to the US measures. China replied almost immediately, threatening tariffs on 50 billion US goods, and reaffirming the start of a trade war by the United States. In December, in the framework of the G20 meeting in Argentina, China and the United States decided to agree on a 90-day truce without imposing additional tariffs, as well as to re-establish negotiations, which are ongoing without clear prospects for a solution.

As important as this trade war is, which has already affected financial markets and international trade, and recalls the harmful effects of the Smooth-Haley law during the Great Depression, it would be illusory to think that the strengthening of protectionism and the withdrawal of countries towards the national space will mean the end of neoliberal globalization. The monopoly-financial capital, both the one that operates in the financial sphere, and the one that moves and delocalizes in the productive sphere towards other geographical spaces, requires the external markets for its reproduction and valorization. The global value chains in which 
this capital participates, forged over decades of internationalization of capital, cannot be removed quickly or easily, even if the governments wish to do so, since these chains were built to a large extent to the super-exploitation of workers from the peripheries and to raise profit rates of TNCs (Smith, 2016; Chesnais, 2016).

The vocation of capital as Marx said since the publication of the Communist Manifesto, is worldwide. But as Nicolas Bujarin understood very well it (1977), the tendency towards the internationalization of capital always clashes with the permanence of national states. The contradiction globalization - national state is irresoluble under capitalism. For that reason more than seeing in the failure of the neoliberal discourse of the Bush's-Clinton era, the end of the trade or financial globalization, it would be necessary to understand that the new right-wing governments will live constantly in the middle of this tension, this contradiction between the global and the national.

Besides this, US aggressive protectionism will hardly solve its trade deficit, since the so-called global imbalances are a structural problem of the US and of the world economy, which could only be solved under global, that is multilateral actions (Roach, 2014). Nor does it seem feasible that the trade war or that the tax cuts will take the United States out of stagnation.

\section{CONCLUSIONS}

The global crisis that broke out in 2007 boosted the deflationary tendencies latent in the global economy since years ago, as well as the withdrawal of national economies inward. After the Great Recession of 2008-2009, most economies (except for China and some Asian economies) have experienced simultaneous processes of economic stagnation, trade deglobalization and reinforcement of protectionist policies. Protectionism has reached their peak during the current trade war between the United States and China, and eventually the European Union.

The global crisis accelerated the decline of the hegemonic position of the United States. While this country maintains a broad military advantage and retains financial hegemony, as the dollar continues to be the key currency of the system, they have lost ground in production, as well as in international trade and foreign direct investment. Unlike the period of undisputed hegemony that the US had during the postwar period, in which centripetal tendencies predominated within the capitalist system, centrifugal tendencies now predominate, while new powers emerge, highlighting the rise of China, which has become in the world leader in productive, trade and increasingly highlights as a financial power.

In the course of recent years, tectonic geopolitical rearrangements have occurred in the world system. It prefigures the formation of a multipolar order, but which is far from configuring a consensual multilateral order with clear rules. New geopolitical alliances unthinkable a few years ago have been formed as those between China, Russia, Iran and Turkey. In any case, multipolarity is appearing in a chaotic scenario in a context in which the global crisis has not been resolved. 
Trump's trade policy will accelerate deglobalization and global fragmentation. And although its tax reform has had a positive short-term effect on economic growth, and unconventional monetary policy from central banks has prevented a depression, it will be difficult for both policies to overcome the "secular stagnation" present for several decades.

Governments and central banks of developed countries face the dilemma of moving towards "monetary normalization" in order to have enough weapons to face the next recession and /or financial crisis or to give it up and continue to feed financial bubbles to keep float the ship, but at the cost of creating the conditions of an even greater crisis in the medium term. As UNCTAD (2018: 7) rightly points out, "if central banks do not reverse the easy money regime, the collapse in asset markets, when it occurs, will be more pronounced and more damaging. On the other hand, if the policy regime (monetary) is reversed, it would abort the recovery that is underway". Face or Cross, bets are accepted!

\section{REFERENCES}

Bujarin, Nicolás (1977). Economía mundial e imperialismo. Córdoba, Argentina, Cuadernos de Pasado y Presente. No. 21

Chesnais, François (2016). Finance Capital Today. Leiden and Boston, Brill.

El Financiero (2018). "Inversión Extranjera Directa cae 41\% en el mundo y 6\% en México en 2018". Mexico, December 25th. http://www.elfinanciero.com.mx/economia/inversion-extranjera-directa-cae-41-en-el-mundo-y-6-en-mexico-en-2018

Europa Press (2018). "La inversión extranjera en países emergentes cae un 9,5\% en 2018, hasta 990.000 millones, según el IIF”. Washington, Europa Press. https://www.europapress.es/economia/finanzas-00340/noticia-inversion-extranjera-paises-emergentes-cae-95-2018-990000-millones-iif-20181003161823.html

Gouyou, Wu [2010], "Economía socialista de mercado”. Brasil \& China em debate. Sao Paulo, Editora Perseu Abramo.

Guillén, Arturo [2015], La crisis global en su laberinto. Madrid, Editorial Biblioteca Nueva-UAMI.

Guillén, Arturo (2007). Mito y realidad de la globalización neoliberal. Mexico, Miguel Angel Porrúa editores-UAMI. México

Guillén, Arturo y Daniel Aparicio (2019). Estancamiento económico en Estados Unidos: un acercamiento a su explicación teórica. Mexico, Mimeo.

Hilferding, Rudolf (1973). El capital financiero. Mexico, Ediciones el Caballito.

IMF (2018). Global Financial Stability Report. A bumpy road ahead. Washington, April. http://www. imf.org/en/Publications/GFSR/Issues/2018/04/02/Global-Financial-Stability-Report-April-2018

Palley, Thomas (2017). The real reasons for Trump's Anti'Globalization Circus. https://www.theglobalist.com/real-reasons-for-trump-anti-globalization-circus/

Petras, James [2015], “China: Rise, Fall and Re-Emergence as a Global Power”. Global Research, May 20th. http://www.globalresearch.ca/china-rise-fall-and-re-emergence-as-a-global-power/29644

Roberts, Michael (2016). The Long Depression. Chicago, Haymarket Books.

Roach, Stephen (2014). Unbalanced. The codependency of America and China. New Haven and London, Yale University Press.

Ross, Wilbur y Peter Navarro (2016). Scoring the Trump Economic Plan: Trade, Regulatory \& Energy Policy Impact. Washington, September 19th https://assets.donaldjtrump.com/Trump_Economic_ Plan.pdf

Roubini, Nouriel y Brunello Rosa (2018). “The Makings of a 2020 Recession and Financial Crisis”. 
Project Syndicate, September 13th, https://www.project-syndicate.org/commentary/financial-crisis-in-2020-worse-than-2008-by-nouriel-roubini-and-brunello-rosa-2018-09?utm_ source=Project $\% 20$ Syndicate $\% 20$ Newsletter\&utm_campaign=a47f3b6f97-sunday_newsletter_ 30_12_2018\&utm_medium =email\&utm_term=0_73bad5b7d8-a47f3b6f97-104374041 \&barrier=accesspaylog

La Jornada (2017). Comenzaremos el muro mucho antes de lo programado: Trump. México, February 25th, http://www.jornada.unam.mx/2017/02/25/politica/003n1pol

Navarro, Peter and Greg Autry (2011). Death by China. Confronting the Dragon. A Global Call to Action. New Jersey, Pearson Education

Navarro, Peter (2006). The Coming China Wars: Where They Will Be Fought and How They Can Be Won. New Jersey, Financial Times Press.

Smith, John (2016). Imperialism in the Twenty-First Century. Nueva York, Monthly Review Press.

TÉLAM [2015]. China, el gran prestamista de los países emergentes. http://www.telam.com.ar/ notas/201504/100310-china-el-gran-prestamista-de-los-paises-emergentes.html

UNCTAD (2018a). World Investment Report 2018. Geneva, UNCTAD. https://unctad.org/en/PublicationsLibrary/wir2018_en.pdf

UNCTAD (2018b). Trade and Development. Report 2018. Geneva. https://unctad.org/en/PublicationsLibrary/tdr2018_en.pdf

UNCTAD (2014). World Investment Report 2014. New York and Geneva. ONU. http://unctad.org/en/ PublicationsLibrary/wir2014_en.pdf

USTRL (2017). 2017 Trade Policy Agenda and 2016 Annual Report of the President of the United States on the Trade Agreements Program. Washington, Office of the United States Trade Representative. https://ustr.gov/about-us/policy-offices/press-office/reports-and-publications/2017/2017 — trade-policy-agenda-and-2016

Wanniski, Jude (1978).The Way the World Works: How Economies Fail-and Succeed. NewYork, Basic Books.

Weeks, John [2016]. "Un enfoque integral de la crisis financiera mundial centrada en América Latina” en Arturo Guillén, Antonina Ivanova, Alicia Girón y Eugenia Correa, coordinadores. Políticas públicas para enfrentar la crisis y alcanzar un desarrollo sustentable. México, Miguel Ángel Porrúa editores-UAMI-UABCS. 